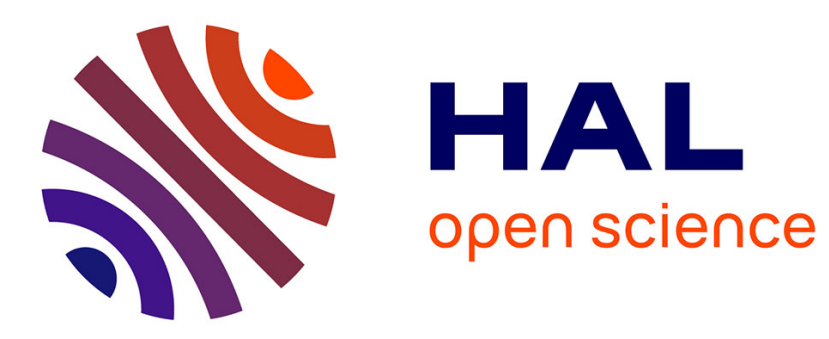

\title{
Co-production of the car as a 'service': involving customers in the value chain
}

Sandrine Ansart, Jean-Jacques Chanaron, Raffi Duymedjian

\section{To cite this version:}

Sandrine Ansart, Jean-Jacques Chanaron, Raffi Duymedjian. Co-production of the car as a 'service': involving customers in the value chain. International Journal of Automotive Technology and Management, 2006, 6 (1), pp.45. 10.1504/IJATM.2006.008935 . halshs-00135705

\section{HAL Id: halshs-00135705 https://shs.hal.science/halshs-00135705}

Submitted on 8 Mar 2007

HAL is a multi-disciplinary open access archive for the deposit and dissemination of scientific research documents, whether they are published or not. The documents may come from teaching and research institutions in France or abroad, or from public or private research centers.
L'archive ouverte pluridisciplinaire HAL, est destinée au dépôt et à la diffusion de documents scientifiques de niveau recherche, publiés ou non, émanant des établissements d'enseignement et de recherche français ou étrangers, des laboratoires publics ou privés. 


\title{
Co-production of the car as a "service": Involving customers in the value chain
}

\author{
Sandrine ANSART \\ Jean-Jacques CHANARON \\ Raffi DUYMEDJIAN
}

\section{Abstract}

This article is dealing with a possible scenario for the future of the automobile thanks to the shift from an artefact vision to a services vision by which the customer might be involved as a true partner in the design of cars. This paper is therefore quite speculative but is challenging the supposedly stabilised relationship between the OEMs and their ultimate clients.

\author{
Key words \\ Automobile, Customers, co-makership, service, value chain
}

\section{Biographies}

Sandrine Ansart is Assistant Professor at the Grenoble Graduate School of Business. She holds a $\mathrm{PhD}$ in international Economics. Her research and teaching concentrate on international economics, industrial and managerial economics with a specific attention on information and knowledge. She is also the head of Management and Behaviour Department.

Professor J.J. Chanaron is currently Research Director within the French National Center for Scientific Research at GATE (Lyon, Ecully) and professor in Technology Management and Economics at the Grenoble Graduate School of Business where he is also the Chief Scientific Advisor. He has published extensively via books, articles in refereed journals and conference papers in Industrial Economics, Economics of Innovation and Technology Management since 1973 when he received his $\mathrm{PhD}$ at the University of Grenoble. He also holds a HDR in Economics. He is Associated Professor and Researcher with Henley Management College, Manchester University and Newcastle University in the UK. $\mathrm{He}$ is a well-recognized expert in the automotive industry. He is consultant to International Organizations (EU, OECD, ILO, UNIDO), professional organizations (CCFA, FIEV, JAMA, CLEPA), OEMs (PSA, Renault, Toyota, Nissan, DaimlerChrysler) and various component manufacturers. He is a member of the French Society of Automotive Engineers (SIA) and the GERPISA International Network of Researchers on the Auto Industry.

Raffi Duymedjian is Assistant Professor at the Grenoble Graduate School of Business. He holds a first First Doctoral Degree in Industrial Engineering at the Ecole Nationale Supérieure de Génie Industriel (Grenoble) and a Master's in Management from the Grenoble Graduate School of Business. His research and teaching concentrate on the use of communication and information systems in organizations. He is particularly focused on the process of managing Knowledge and creating collaborative structures. He is currently exploring ways by which the concept of bricolage can be used to enrich the analysis of the incremental innovation process. He also has interest in learning technologies, i.e. multimedia and web for improving learning processes. 
Since the late nineties, e-business has become one of the key weapons for strategists in the business community, and in particular in the automotive industry. All sectors of the industry are raising questions about e-business:

- What effects might have this new way of operating?

- Why and how to use it?

- For which functions: design, purchasing, finance, communication, sales, aftermarket, etc.?

- What are its costs and benefits?

Within the automotive industry, all players - OEMs, component suppliers, dealers, etc. - have already largely integrated e-business functions into their value chain and their organizations, using it to partly manage the business-to-business relations, i.e. the supply chain (B2B). But however, despite very optimistic statements made by most industry experts in the late nineties, the development of e-business for business-to-customer relations (B2C) is still very limited. 


\section{An Official EU Definition}

Electronic commerce is about doing business electronically. It is based on the electronic processing and transmission of data, including text, sound and video. It encompasses many diverse activities including electronic trading of goods and services, on-line delivery of digital content, electronic fund transfers, electronic share trading, electronic bills of lading, commercial auctions, collaborative design and engineering, on-line sourcing, public procurement, direct consumer marketing and after-sales service. It involves both products (e.g. consumer goods, specialised medical equipment) and services (e.g. information services, financial and legal services); traditional activities (e.g. healthcare, education) and new activities (e.g. virtual malls).

Source: European Commission, (1997).

This article aims at examining potential use for e-business in the B2C relationships. Its basic belief is that although there is no doubt about the necessity of Internet sites to serve as "electronic windows", there are plenty of opportunities beyond the "sales function", i.e. the management of all the information available prior to the physical transaction itself (basically the car delivery). The main hypothesis is that e-business might be part of the intermittent relationship between manufacturers and customers based on new forms of interaction. The evolution of the "car" towards a more global "transportation service" concept might force OEMs to build up new relationships with their customers with a more long term scope. In particular, e-business might contribute to develop a co-makership relation by which the customers and the OEMS would enter in a "partnership" within the value chain of the product as a whole. New information and communication technologies (NICT) could then be used as support of such relations. For the manufacturers (OEMs and their suppliers), since such projects are already being put into place, an important question is raised: what competencies are required from both the customers and the manufacturers?

The paper will deal with four key issues:

1. What is the current situation for e-business in the automobile B2C?

2. What is the reality of the move towards a "transportation service"?

3. What are the roles of each part of the value chain?

4. What are the required competencies?

Obviously, this contribution is by nature very speculative since most trends are not yet strictly visible but only foreseeable and also because there is no generally accepted theories and business models. The literature available is still also very speculative and then very challengeable and controversial. Within the academic community on the automotive industry, very few researchers have already dealt with the customer side of the transaction, 
giving priority to the supply side. This article is also mainly based on information and in-depth knowledge limited to the French case.

\section{Current State-of-the-Art in the B2C Relationship}

All data concerning e-business in the automotive industry are still to be used very cautiously because they are produced by the e-business community itself, including enthusiastic consulting companies such as Forrester Research, Merryll Lynch and Gartner Group as well as Accenture, McKinsey and KPMG.

\subsection{Estimating Internet Sales}

In the late nineties and up to the end of the bubble, the Internet has been considered by experts as a key weapon for gaining competitive advantage (Rapp, 2000). Experts were then more than enthusiastic and this is now proven they were far too much optimistic.

The market share of Internet is still very low. In the United States, it was $3 \%$ in 2001. It means that only 400000 vehicles $^{1}$ have been sold through Internet. According to these data, European customers are then far behind the Japanese and Americans. Most OEMs decline to offer sales figures. Therefore, existing data are far from being reliable.

Table 1. Percentage of Sales Made Through Internet

\begin{tabular}{|l|c|c|}
\hline Country & \% of Sales in 2001 & \% of Sales in 2000 \\
\hline Japon & $5.4 \%$ & \\
\hline USA & $3.0 \%$ & $1.6 \%$ \\
\hline Germany & $1.6 \%$ & \\
\hline UK & $1.1 \%$ & \\
\hline France & $0.2 \%$ & \\
\hline $\begin{array}{l}\text { Source: CGEY (2001) } \\
\text { http://www.institut.qc.ca/veille ice/ianvier02/sem03.html. }\end{array}$ \\
\hline
\end{tabular}

As far as e-commerce in general is concerned, it has to be pointed out that the widespread introduction of Minitel service in the eighties has made France one of the most ecommerce advanced countries. A survey has shown that $39 \%$ of all companies with more than 10 employees utilize some kind of electronic commerce to conduct business.

But automobile is far from being a leading industry. In its most recent survey, Andersen (2001) does not even identify automobile as a product dealt with on Internet in its 
data on Internet channel for selected items (books, records, videotapes, software, PCs, other electronic equipments, clothes, toys, food, travels and airplane tickets). They found out that there is no stabilized business model for selling cars on Internet. In Andersen's typology, automobile is one of the two "bad boys" of the e-commerce together with flowers.

\subsection{Which functionalities?}

There are also great uncertainty and diversity concerning the functionalities achieved by automobile Internet commercial sites. So far, according to a survey published by Cap Gemini-Ernst \& Young in October 2001, Internet sites are mainly used as source for information and inspiration in order to analyze and compare technical characteristics and performances as well as prices. In $2001,38 \%$ of customers are satisfied with Internet sites for such a function. This proportion has increased from $27 \%$ in 2000.

Table 2. A Functional Framework

\begin{tabular}{|l|l|}
\hline Generic Functions & Detailed Functions \\
\hline Electronic Window & Product presentation \\
\hline & Image and notoriety building \\
\hline & Editorial content \\
\hline & Topical content \\
\hline & Product personalization \\
\hline & Commercial animation \\
\hline Marketing & Search engine \\
\hline & Community building \\
\hline & Direct advertisement \\
\hline & Consumer loyalty management \\
\hline & Interactivity and personalization \\
\hline Logistics/Administration & Customer recognition \\
\hline & Delivery \\
\hline & Order management \\
\hline Cashing In/Transaction & Multi channel integration \\
\hline & Car selling process \\
\hline & Invoicing \\
\hline & Payment security \\
\hline Source: Adapted from Andersen, 2001. \\
\hline
\end{tabular}

It has to be pointed out that some transactions on second-hand cars are traded through consumer-to-consumer (C2C) sites mainly through on-line auctioning and that consumer-to-business (C2B), i.e. consumer collective bargaining with businesses is not yet developed for cars. For fleet managers, direct negotiation is still the best practice.

\footnotetext{
${ }^{1}$ It is not said precisely if this is only for new vehicles.
} 
Compared to the United States, France is relatively late and weak as far as the number of automobile-related Internet sites is concerned.

This is clear that Internet is still a purely informational channel, a new media in providing the customers with information related to vehicle specifications, performances and prices, as well as "virtual" visit and /or driving for the most sophisticated web sites..

\section{From the Car as an "Artifact" to the Car as a "Service"}

It is usually through services other than the actual sale of the vehicle that the evolution of the "automobile" statute is occurring: financing, insuring, maintaining, repairing, renting, etc ${ }^{2}$. This statute moves progressively from a "product" to a "service" or even better to "a full package of services". This evolution, which is indeed in its very early stage, is a deeply rooted change which is produced simultaneously by the increasingly intense competition among car manufacturers (OEMs) and among dealers and by change in customer behavior.

\subsection{OEMs and customer-oriented strategies}

Despite the intense and growing competition amongst OEMs, the customer was not really taken into account until the middle of the 1990s. The lack of concern was easily explained by the dominant distribution channels and methods in place. The dealership then functioned as a filter between the vehicle manufacturers and their final customers.

\subsubsection{The "isolation" of manufacturers from their customers}

The idea of limited contact between manufacturers and customers may seem relatively paradoxical when considering the situation of over capacity that has characterized the automobile industry since the 1970s. This era was the time of cost reductions and exaggerated marketing support. Nobody would challenge the fact that OEMs have made considerable efforts concerning prices and quality as well as increasing the variety and efficiency of equipment. But they did not pay attention to the services to customer and above all to customer satisfaction. They were simply imposing their choices considering their customers as fully trusting their knowledge and competencies.

\footnotetext{
${ }^{2}$ The rapid growth of these kinds of contracts is a result of the offer and of customer interest. It would seem that in Europe, the notion of ownership is more acute than in the United States. It might also be referred to the level of savings: much higher in Europe than in the United States, while household debt is much higher for the Americans than the Europeans.
} 
For decades, new car sales have been organized through dealer networks (Chanaron, Jullien, 1997). As a result, the OEMs have given away their control over sales of new and second hand cars, maintenance, spare parts distribution and other activities such as credit and insurance.

Figure 1. The turnover of the average dealer in France (2000)

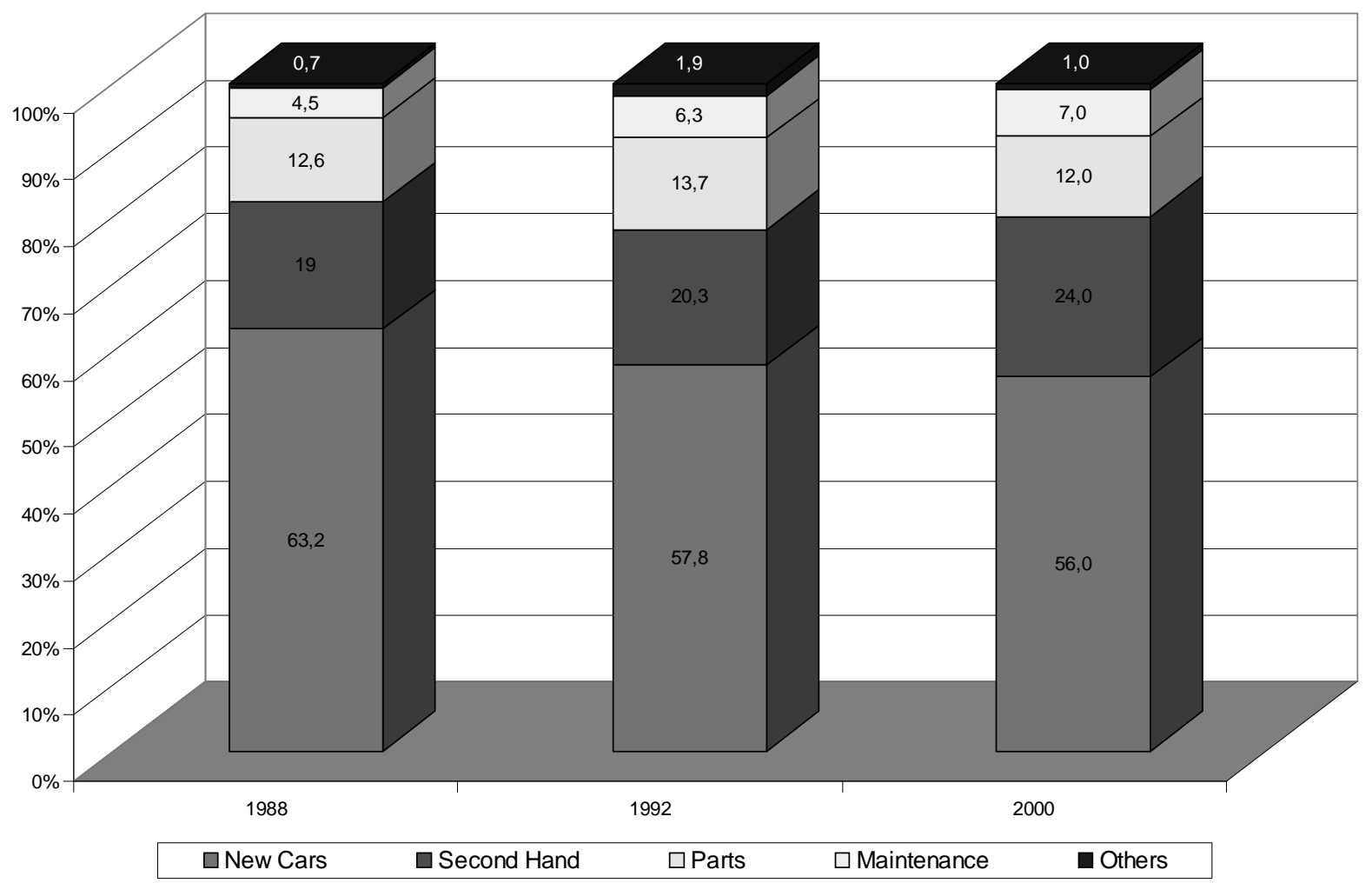

Source: Observatoire, 2002.

It has to be pointed out that new car sales are the smallest contribution to dealers' profits: for example, $36 \%$ of gross margin in France and $56 \%$ of turnover in 2001 and $0.4 \%$ of total net profits in Germany in $2001^{3}$.

The vehicle manufacturers transferred to relatively independent agents the control of sales and the organization of all the sales-related services (Cornette, Pontier, 2001). Such a structure engendered a situation in which these crucial activities were very much ignored and badly understood, and therefore marketing and commercial departments were neglecting the concept and the function of service.

\footnotetext{
${ }^{3}$ Handelsblatt, 13/03/2002.
} 


\subsubsection{Challenge from a changing distribution process}

Delegating the bulk of sales and after-sale services has been a deliberate choice by OEMs and until recently, they were quite satisfied with such a choice. In the middle of the nineties, however, and particularly with the influence of new and more aggressive sales strategies introduced by some independent dealers, in particular huge multi-brand distribution groups, the OEMs began to have a different perception of these activities. They started to realize two fast emerging trends:

1. These services might be of substantial contribution to their overall profit margin compared to the profits derived from sales of new vehicles;

2. They might rapidly appear as key elements for the future of the automobile industry itself if the customers would base their choice not only on the design and performances of cars but also if not mainly on complementary services.

New structures such as mega stores (Jullien, 1998, 2001) have been much more customer satisfaction oriented through a wider variety of cars, brands and services offered. They also demonstrated the new interest in customer comfort during the actual purchasing process: waiting rooms, vending machines, childcare, picnic tables, etc.

\subsection{New consumer behavioral influences"}

To boost sales, all manufacturers are constantly searching for those elements which will shape customers preference and selection for a particular brand., whether it is based on the characteristics of a product or a new product. Brand loyalty is a key strategic weapon. Manufacturers also look for services that would facilitate sales. Some are even looking to turn their products into services. One of our main assumptions is that the automobile manufacturers have reached or are very close to this point.

Why are they considering such conception? The answers seems to come from some changes in customers' behavior. Three major trends point to the potential interest that customers may have in the car as a "service." The two first trends can be qualified as "financial reasons," while the other is more closely related to a major change in lifestyle.

1. The car is less and less a symbol of social success but as a normal good ("as a commodity) used for transportation without any ostentatious characteristic; 
2. The car is more and more seen as an expenditure and not any more as an long term investment. Customers see their car as a part of their annual budget which is split into purchasing cost (annual depreciation) and costs related to the use of the product (maintenance, spare parts, gasoline, etc.);

3. "Having access to a car" has taken precedence over "owning one's own car" because using a car is not always a pleasure (traffic jams, speed limits, fines, etc.): it is a simple tool that should fit with the existing system for mobility;

Figure 2. The average household automobile budget 1990-2000 in France

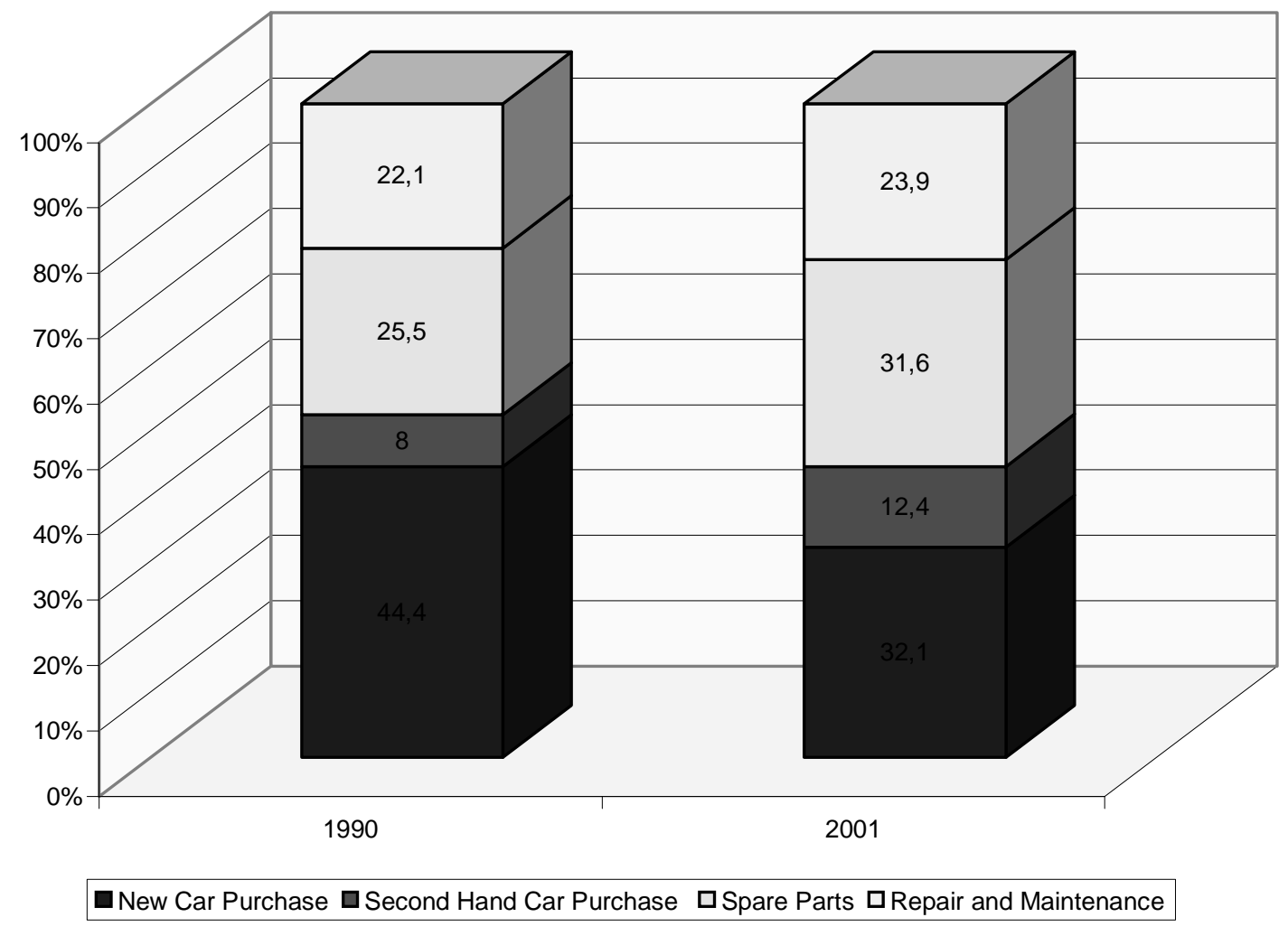

The car is now seen as one of the technical tools for the "transportation function" that requires increasingly important features such as user friendliness, product adaptability and regular renewal. Consumers in general and drivers in particular, are increasingly attracted by products that:

- Are adaptable to their needs,

- In perfect condition,

- Respects all standards and regulations,

\footnotetext{
4 "Given that production methods, infrastructures, goods and services are becoming obsolete much faster (...), long term ownership of goods is becoming less popular, whereas short term access is a more frequently chosen option" [Rifkin, 2001].
} 
- Offers all the latest technologies.

\section{Required Competencies in Creating Long Term OEM-Customer relationship}

The new consumer attraction to this concept of "having access to a car" supports the development of the "service" car or the "transportation service." The concept of service requires an increased knowledge of the customer needs and willingness. One of the best ways to adapt to this new mode of operation is in "co-producing" or co-making the service; i.e. through collaboration between the manufacturer and the consumer in the development of the offered package of services. Such deal requires a real cooperation that to be truly effective might bring together three conditions:

1. The creation of a common language,

2. Mutual trust,

3. A regulated interaction.

\subsection{Creating a common language}

A common language between OEMs and consumers is the first condition. In any dialogue, there must be a common interest and a common language. The dialogue must rely on shared knowledge about the core subject.

\subsubsection{Highly knowledgeable consumers}

One of the major difficulties involved in creating cooperation between the OEM and the consumer is the consumer's commitment. As pointed out by Buzzavo \& Volpato (2001), customers become much more information-rich thanks to new information and communication technologies which are strengthening and increasing the already significant role of automobile magazines. Internet sites provide information on:

- Vehicle specifications;

- Performances, reliability and quality;

- Prices, rebates and incentives;

- Availability,

- Associated services. 


\subsubsection{OEMs as a "Teaching organization"}

So far, consumers have been more easily attracted to the car as an object (emphasizing specifications and performances) than to the car as a service. It is thus important to inform them of this new "service" concept, and even better, to teach them about it. This service concept would be the catalyst for a new form of long term relationship between the OEMs and their customers as well as a justification for new types of solicitation by the manufacturers. In this new relationship, the role of the OEM is shifting from investigator to teacher. In this respect, Customer Education is becoming more and more important for companies wanting to implement a competitive strategy based on service quality [Burton, 2002]. This strategy implies evaluating services on many criteria such as the complexity of service, the rate of service innovation, etc. However, as a new way of building competitive advantage, "the consumer education-service quality debate is to design appropriate methods that simultaneously fulfill the needs of consumers at a time and place where they are most beneficial but in a cost effective manner." [Burton, 2002, p.138].

Because, information-education can, then, be seen as a continuum [Burton, 2002, p.130], diffusion of information is at the heart of this new relationship. Providing the appropriate information and the tools and means to assimilate information is a crucial part of the teaching function. Consumers should realize that this relationship is not unidirectional. They have a role to play, and this role requires a minimum level of competence.

In order to set up co-makership with customers OEMs should combine three complementary conditions: an intellectual principle, a space and methods for dialogue.

1. The required intellectual principle aims at partly reversing the function of designers and users from a unilateral definition of rules by the designer to a multilateral relationship. Historically, the OEMs did define the conditions and limits for the use of their products, not only integrating them in the vehicle physical characteristics but also in documents and contractual specifications (in particular for after sales services). The customer used to be supposed as following and applying such rules, any other attitude being excluded if not punished as deviant (exclusion from contractual guarantee).

The current evolution is towards considering heterodox behaviors, qualified as DIY (do it yourself) by De Certeau (1990), as a source of value and innovation since they

\footnotetext{
${ }^{5}$ We would like to expand the definition of Peter Drucker's teaching organizations, i.e. « corporations (which) encourage their managers to regularly take on the role of teacher within the company so as to share part of their expertise" [Drucker, 1999] by defining it also as companies willing to train other stakeholders, namely suppliers and customers.
} 
express the beneficial diversity and variety of customer attitudes. There is a need for a new dynamics based on jurisprudence.

2. There is also a required "space" for a real and efficient dialogue between OEMs and their customers regarding the product-service. Traditional market tests, marketing surveys used to be such "space" for dialogue. New Information and Communication Technologies are tremendous opportunities for a dramatic extension of the OEM-customers dialogue. There could be "invisible" links through direct communication with each vehicle. NICT could also open more verbal exchanges through forums and chats, providing violent intrusions such as automatic e-mailing or cookies are strictly limited and regulated.

3. It is also important to develop specific competencies to support such dialogue, in particular in building up, diffusing and manipulating information. Such an extended dialogue requires a mutual learning for both parties, and therefore to introduce pedagogy in the OEM-customer relationship. E-learning might be a well adapted media. But its development requires a full control of information system organization and management (Wurman, Sume, Leiffer, 2001). Pedagogical information are different from and complementary to commercial and marketing information. NICT are actually allowing a wide variety of communication modes from clearly separated channels up to hybrid forms such as edutainment.

It is on such bases that a dialogue between designers and manufacturers and their final customers and end-users could build up co-makership of product-service. Obviously, the still dominant position of the OEMs in the implicit "contractual relationship" gives them an unavoidable leadership (Eisner, 1998). But a progressive move towards a more balanced relationship might be considered as foreseeable.

\subsection{Mutual trust}

Once the new competencies have been acquired by both the OEMs and their customers, there is a need for mutual trust in order to create this common language and thus open the dialogue: Trust has rarely been considered a critical element for the success of exchange with final customers. In the co-makership deal, new foundations for exchange should be integrated into the process.

\subsubsection{Trust in traditional transactional exchange}


In conventional economic theory, centered on transactions, exchange is totally asymmetrical: a good is exchanged for a monetary value. But trust is not necessarily required for a standard approach of economic transaction. Strategies focused on customer loyalty do not refer to the construction of a trust-based relationship, but are backed by the finding that a sale to a new customer costs ten times more than the same sale to a loyal customer. In the new business model named "co-produced service", the relationship with the customer is in intermediate position between a purely transactional one and a hierarchical one. Partnership might require the creation of a specific contract.

These new relationships between OEMs and customers call for new competencies. Some of them should be structured and properly managed. Contractual relationships might well be a dominant form.

In the new model, there are new characteristics that change dramatically the very nature of the relationship:

- Long term instead of short and medium term;

- Multilateral relationships instead of bilateral;

- Multiform or rather recurring instead of one-shot: information on new products, product modifications, users guides, financing opportunities, loyalty rewards, motor sport events, motor shows, trials, etc.

Such new elements are introducing an in-depth change and require a "contractualization" which will stipulate the terms of agreement. The quality of the relationship will be based on the quality of the information given by the OEM over the agreed period and the resultant brand loyalty of the customers.

\subsubsection{Trust and new technologies: the need for visible efforts}

The OEM/customer relationship in the emerging co-production model would be eased by the use of new information and communication technologies (NICT), and in particular Internet-based medias. As one their purpose is to better handle and disseminate information, they have obviously a key role in this process. Beyond the inevitable differentiation created between connected and not connected customers, the use of these new technologies might prove to have a destabilizing effect on the trust-based relationship. 
By their very nature, NICT should be invisible and transparent. Their role is to lend support to traditional activities by facilitating the handling and structuring of information, its diffusion and distribution. They are, above all, technical supports that after a short time become mundane in their use and are considered as given services, quite close to a public good. Once the customers have been trained, the OEMs might rapidly appear to be simple source of information and might look like detached from the relationship with their customers.

OEMs need to build up a so-called "willingness convention" or contract (Gomez, 1994) and its visibility to the customers. Such a convention demonstrates the OEM's commitment and therefore investment to create a long-lasting relationship based on trust. In other words, in order to remain "trustable",

\subsection{A regulated interaction}

Finally, the third condition required for the creation of the co-makership deal is the definition of clear rules for the governance of the interaction between the two parties. The inherent dissymmetry in information and bargaining power should be substantially decreased $^{6}$. Successful communication requires clarity of standards and full awareness concerning the stakes that define the rules for interaction.

The OEMs would expect the consumers to be available to express their opinions and suggestions. In return, the consumers would expect to receive a detailed explanation concerning the validity and the future of the suggestions made. This back and forth relationship should be formalized, possibly through a written contract with legal dimensions. The communication should follow procedures and principles that stipulate the methods of exchange.

\section{Conclusion}

The business model in which the car will be marketed as a full service package might well be a revolutionary opportunity for the OEMs, the suppliers and indeed the customers:

- For the industry itself (OEMs and their supply chain), this might be a new source of activity and profitability;

\footnotetext{
${ }^{6}$ Such a dissymmetry between staff and executives explains the failure of quality circle in France.
} 
- For the OEMs and the customers, this might be an opportunity to establish a new form of relationships.

This article assumes that these new orientations would probably be largely dependent on the implementation of e-business technologies. E-business-to-customer would provide the support for the required management of increasing amount of information. It would require the development of new competencies for both parties. OEMs should become a training organization in order to train their customers when the customers should learn how to be involved in the design and development of the product (the car) as well as the associated services. Although this is a huge challenge, the automobile manufacturers could, however, be precursors because they benefit from a customer base whose level of interest and knowledge about the product is quite significant. For more than a century, the automotive industry has been the leading industry for innovation in high volume markets of technologically complex products.

It is obvious that further research is urgently needed. The most ambitious and perhaps difficult one would be to expand the current knowledge of the demand mechanisms. This has been far too much neglected by the research community in economics. Some development has been made in management sciences mainly by marketing researchers. But this far from being sufficient, in particular because this is a fast changing market under heavy competition on price, variety and technology.

The emergence of the Internet economy is already and will be even more in the future a real challenge for research in economics and management. The automotive industry, as always, is leading the manufacturing sector. This is an ideal field for applied research. 


\section{Bibliography}

ANDERSEN (2001), La deuxième vague du e-commerce ou les nouvelles stratégie de croissance, Etude e-Business, Octobre.

BUZZAVO, L., VOLPATO, G., (2001), Car Distribution in Europe, Between Vertical Agreements and Customer Satisfaction, Cockeas Meeting, Berlin, 30 November.

De CERTEAU, M. (1990), L'invention du quotidien, Arts de Faire, Tome 1, Gallimard.

CHANARON, J.J., JULLIEN, B. (1997), Fabrication, distribution et réparation automobile : nouvelles cohérences et nouvelles compétences, in CHANARON, JJ, FUJIMOTO, T., LUNG, Y. and RAFF D (Eds), Coping with variety. Product Variety and Productive Organization in the Automobile Industry, Ashgate, Aldershol.

CORNETTE G \& PONTIER S (2001), D'un marketing à l'autre: les évolutions de la distribution automobile aux Etats-Unis, First Franco-Japanese Workshop on e-commerce, ESC Grenoble, October.

BURTON, D., (2002), Consumer education and service quality: conceptual issues and practical implications, JOURNAL OF SERVICES MARKETING, VOL. 16 №2, pp. 125-142,

DRUCKER, P., (1999), Managing Knowledge Worker in a Changing World, in R. Ruggles and D. Holtshouse, (eds.) The Knowledge Advantage, NH-US, Capstone US, Business Books Network.

EISNER,W., (1998), Le récit graphique, Paris, Vertige Graphic.

EUROPEAN COMMISSION, (1997), A European Initiative in Electronic Commerce, COM(97) 157.

JULLIEN, B. (2001), La distribution automobile en 2000 : vers le partenariat ou la taylorisation?, Actes du Gerpisa, n³1, avril.

JULLIEN, B. (1998), Les constructeurs face aux nécessaires mutations de la distribution : quelles leçons tirer des rapides évolutions en cours aux Etats-Unis ?, Actes du Gerpisa , n²3.

GOMEZ, P.-Y., (1994), Qualité et économie des conventions, Economica, Paris.

OBSERVATOIRE, (2002), Distribution Automobile et perspectives du marché en 2002, retrieved on 18/03/2002 from www.observatoire.com/publicat/distrib2002/distribution.htm.

RAPP, W.V. (2000), Automobiles: Toyota Motor Corporation: Gaining and Sustaining Long-term Advantage Through Information Technology, Working Paper of Center on Japanese Economy and Business for Columbia-Yale Sloan Foundation Project: Use of Software to Achieve Competitive Advantage, Columbia, NY, retrieved on 03/11/2001 from http://web.njit.edu/ rappw/publications.htm.

RIFKIN, J., (2001), L’âge de l'accès, La Découverte, Paris.

WURMAN, R.S., SUME, D., LEIFER, L., (2001), Information Anxiety 2, QUE. 